\title{
Effect of lutein on methotrexate-induced oxidative lung damage in rats: a biochemical and histopathological assessment
}

\author{
Renad Mammadov ${ }^{1}$, Bahadir Suleyman ${ }^{1}$, Selcuk Akturan ${ }^{2}$, Ferda Keskin Cimen ${ }^{3}$, Nezahat Kurt ${ }^{4}$, \\ Zeynep Suleyman ${ }^{5}$, and İsmail Malkoc ${ }^{6}$
}

Departments of ${ }^{1}$ Pharmacology, ${ }^{2}$ Family Medicine, and ${ }^{3}$ Pathology, Erzincan University Faculty of Medicine, Erzincan; ${ }^{4}$ Department of Biochemistry, Ataturk University Faculty of Medicine, Erzurum; ${ }^{5}$ Department of Nursing, Erzincan University Faculty of Health Sciences, Erzincan; ${ }^{6}$ Department of Anatomy, Ataturk University Faculty of Medicine, Erzurum, Turkey

Received: April 18, 2018 Revised: September 11, 2018 Accepted: October 26, 2018

\section{Correspondence to}

Renad Mammadov, M.D.

Department of Pharmacology, Erzincan University Faculty of Medicine, Basbaglar Street, Erzincan 24100, Turkey

Tel: +90-507-0115922

Fax: +90-446-2261819

E-mail: renad_mamedov@hotmail. com
Background/Aims: This study aimed to investigate the effect of lutein on methotrexate (MTX)-induced pulmonary toxicity in rats biochemically and histopathologically.

Methods: The rats in the MTX + lutein (MTXL, $\mathrm{n}=6$ ) group were given $1 \mathrm{mg} / \mathrm{kg}$ of lutein orally. A $0.9 \% \mathrm{NaCl}$ solution was administered orally to the MTX $(\mathrm{n}=6)$ group and the healthy group ( $\mathrm{HG}, \mathrm{n}=6$ ). One hour later, a single $20 \mathrm{mg} / \mathrm{kg}$ dose of MTX was injected intraperitoneally in the MTXL and MTX. Lutein or $0.9 \%$ $\mathrm{NaCl}$ solution was administered once a day for 5 days. At the end of this period, malondialdehyde (MDA), myeloperoxidase (MPO), total glutathione (tGSH), interleukin 1 beta (IL-1 $\beta$ ), and tumor necrosis factor alpha (TNF- $\alpha$ ) were measured in the lung tissues from the animals euthanized with $50 \mathrm{mg} / \mathrm{kg}$ thiopental sodium anesthesia. Subsequently, histopathological examinations were performed.

Results: The levels of MDA, MPO, IL-1 $\beta$, and TNF- $\alpha$ in the lung tissue of the MTX were significantly higher than those of the MTXL and HG groups $(p<$ 0.0001 ), and the amount of tGSH was lower. The histopathological findings in the MTX group, in which the oxidants and cytokines were higher, were more severe. Conclusions: Lutein prevented the MTX-induced oxidative lung damage biochemically and histopathologically. This result indicates that lutein may be useful in the treatment of MTX-induced lung damage.

Keywords: Methotrexate; Lung; Lutein; Rats

\section{INTRODUCTION}

Methotrexate (MTX) is a folic acid antagonist drug that inhibits dihydrofolate reductase and reduces the levels of tetrafolate in cells [1]. MTX has been widely used for nearly 20 years in the treatment of cancers (acute lymphoblastic leukemia, sarcoma, lung, breast, and bladder cancer) and inflammatory diseases (psoriasis, multiple sclerosis, and rheumatoid arthritis) because of its antiproliferative effect [2-4]. Whereas MTX is used in in- flammatory diseases at $20 \mathrm{mg} / \mathrm{m}^{2}$ weekly, it is applied in oncological diseases in high doses of 1,000 to 33,000 $\mathrm{mg} / \mathrm{m}^{2}$ [5]. Cough, dyspnea, fever, pneumonia, interstitial lung disease, and lung fibrosis were seen in $60 \%$ to 93\% of patients treated with MTX [6]. This toxic effect leads to the discontinuation of MTX treatment in 30\% of patients [7]. MTX-induced pulmonary toxicity may develop because of low dose use, but it more frequently occurs with high doses. Interstitial infiltrations associated with MTX, a common alveolar damage associated 
with perivascular inflammation, were reported to be seen in lung biopsies [3]. The increase in malondialdehyde (MDA) and myeloperoxidase (MPO) levels and the decrease in glutathione (GSH) levels are considered to be responsible for the pathogenesis of MTX-induced lung damage. MDA and MPO are oxidants, and GSH is an endogenous antioxidant [8]. This information suggests that oxidative stress is potentially causal in MTX-induced lung toxicity. In addition, an overdose of MTX was reported to cause the release of proinflammatory tumor necrosis factor alpha (TNF- $\alpha$ ) and interleukin 1 beta (IL-1 $\beta)[9,10]$. This result reveals that the combined effects of anti-inflammatory and antioxidant drugs would be beneficial in the prevention of MTX-induced lung toxicity. Lutein is a tetraterpenoid [11]. Its molecule has two hydroxyl groups, and it has an antioxidant property [12]. Moreover, lutein was reported to have anti-inflammatory effects [13]. Lutein provides antioxidant and anti-inflammatory activities by inhibiting lipid peroxidation, TNF- $\alpha$, IL-1 $\beta$, and nuclear factor kappa B (NF- $\kappa \beta)$ production and by preventing the reduction of GSH levels [14]. Therefore, lutein may be useful in preventing MTX pulmonary toxicity. There is no evidence yet of the protective effect of lutein on lung toxicity in the literature. Therefore, this study aims to investigate the effect of lutein on MTX-induced pulmonary toxicity in rats biochemically and histopathologically.

\section{METHODS}

\section{Animals}

A total of 24 albino Wistar male rats weighing 250 to 265 $\mathrm{g}$ were used in the experiment. All rats were obtained from the Ataturk University Medical Experimental and Research Center. The animals were housed and fed under appropriate conditions at normal room temperature $\left(22^{\circ} \mathrm{C}\right)$ in the appropriate laboratory environment. The protocols and procedures were approved by the local Animal Experimentation Ethics Committee (Meeting 22.12.2017, Issue 14, Decision number 183).

\section{Chemical substances}

The materials used in the experiment were obtained from the following: lutein from Solgar (Leonia, NJ, USA), MTX from Med-Ilac (Istanbul, Turkey), and thiopental sodium from Dr. Ibrahim Etem Ulagay (Turkey).

\section{Experimental groups}

The animals were divided into three groups, namely, healthy group (HG), MTX-administered, and MTX + lutein (MTXL)-administered groups.

\section{Experimental procedure}

The rats in the MTXL ( $\mathrm{n}=6)$ group were given $1 \mathrm{mg} / \mathrm{kg}$ of lutein orally [15]. About $0.9 \% \mathrm{NaCl}$ solution was administered to the MTX $(n=6)$ and HG $(n=6)$ groups through the same method. One hour later, a single dose of $20 \mathrm{mg} / \mathrm{kg}$ MTX was injected intraperitoneally into the MTXL and MTX groups. Lutein and 0.9\% $\mathrm{NaCl}$ solution were administered once a day for 5 days. At the end of this period, MDA, MPO, total glutathione (tGSH), IL-1 $\beta$, and TNF- $\alpha$ were measured in lung tissues from the animals killed with $50 \mathrm{mg} / \mathrm{kg}$ thiopental sodium anesthesia. Afterward, histopathologic examinations were performed on the lung tissues. Biochemical experiments were performed only once. All experimental results were evaluated by a comparison between groups.

\section{Biochemical analysis}

MDA analysis in tissue

MDA measurements were based on the method used by Ohkawa et al. [16] involving the spectrophotometrical measurement of the absorbance of the pink-colored complex formed by thiobarbituric acid and MDA. The serum/tissue homogenate sample (0.1 $\mathrm{mL}$ ) was added to a solution containing $0.2 \mathrm{ml}$ of $80 \mathrm{~g} / \mathrm{L}$ sodium dodecyl sulfate, $1.5 \mathrm{~mL}$ of $200 \mathrm{~g} / \mathrm{L}$ acetic acid, $1.5 \mathrm{~mL}$ of $8 \mathrm{~g} / \mathrm{L}$ 2-thiobarbiturate, and $0.3 \mathrm{~mL}$ distilled water. The mixture was incubated at $95^{\circ} \mathrm{C}$ for 1 hour. Upon cooling, 5 $\mathrm{mL}$ of n-butanol:pyridine (15:1) was added. The mixture was vortexed for 1 minute and centrifuged for 30 minues at $4,000 \mathrm{rpm}$. The absorbance of the supernatant was measured at $532 \mathrm{~nm}$. The standard curve was obtained using 1,1,3,3-tetramethoxypropane [16].

MPO activity analysis in tissue

According to the method defined by Bradley et al. [17] to determine MPO activity in tissue homogenates, $\mathrm{H}_{2} \mathrm{O}_{2}$ involved in phosphate buffer (50 mM, pH 6) was used as the substrate. The assay buffer was prepared $(7.5 \mathrm{mg}$ o-dianisidine- $\mathrm{HCl}, 5 \mathrm{~mL} 0.0005 \% \mathrm{H}_{2} \mathrm{O}_{2}$ in $40 \mathrm{~mL}$ phos- 
phate buffer), and $20 \mu \mathrm{L}$ serum/tissue homogenate was added to $280 \mu \mathrm{L}$ assay buffer. The MPO activity was kinetically measurement at $460 \mathrm{~nm}$ for 5 minutes [17].

tGSH analysis in tissue

According to the method defined by Sedlak and Lindsay [18], 5,5'-dithiobis (2-nitrobenzoic acid) (DTNB) disulfide is chromogenic in the medium and is reduced easily by sulfhydryl groups. The yellow color produced during the reduction was measured by spectrophotometry at $412 \mathrm{~nm}$. For measurement, a cocktail solution $(5.85 \mathrm{~mL}$ $100 \mathrm{mM}$ Na-phosphate buffer, $2.8 \mathrm{~mL}$ 1 mM DTNB, 3.75 $\mathrm{mL} 1 \mathrm{mM}$ nicotinamide adenine dinucleotide phosphate, and $80 \mu \mathrm{L} 625 \mathrm{U} / \mathrm{L}$ GSH reductase) was prepared. Before measurement, $0.1 \mathrm{~mL}$ meta-phosphoric acid was added to $0.1 \mathrm{~mL}$ serum/tissue homogenate and centrifuged for 2 minutes at 2,000 rpm for deproteinization. The $0.15 \mathrm{~mL}$ cocktail solution was added to $50 \mu \mathrm{L}$ of the supernatant. The standard curve was obtained using glutathione disulfide [18].

IL-1 $\beta$ analysis in tissue

The tissue homogenate IL-1 $\beta$ concentrations were measured using the rat-specific sandwich enzyme-linked immunosorbent assay rat IL-1 $\beta$ enzyme-linked immunosorbent assay (ELISA) Kit (Cat no: YHBo616Ra, Shanghai LZ, Shanghai, China). The analyses were performed according to the manufacturer's instructions. Briefly, a monoclonal antibody specific for rat IL-1 $\beta$ was coated onto the wells of the micro plates. The tissue homogenate, standards, and biotinylated monoclonal antibody-specific and streptavidin-horseradish peroxidase (HRP) were pipetted into these wells and then incubated at $37^{\circ} \mathrm{C}$ for 60 minutes. After washing, chromogen reagent $\mathrm{A}$ and chromogen reagent $\mathrm{B}$ were added, and they acted upon by the bound enzyme to produce a color. They were incubated at $37^{\circ} \mathrm{C}$ for 10 minutes, and then a stop solution was added. The intensity of this colored product was directly proportional to the concentration of rat IL-1 $\beta$ present in the original specimen. At the end of the course, the well plates were read at $450 \mathrm{~nm}$ using a microplate reader (Bio-Tek, Winooski, VT, USA). The absorbance of the samples was estimated with formulas that used standard graphics.
TNF- $\alpha$ analysis in tissue

The tissue homogenate TNF- $\alpha$ concentrations were measured using the rat-specific sandwich enzyme-linked immunosorbent assay rat TNF- $\alpha$ ELISA kits (Cat no: YHB1098Ra, Shanghai LZ). The analyses were performed according to the manufacturer's instructions. Briefly, a monoclonal antibody specific for rat TNF- $\alpha$ was coated onto the wells of the microplates. The tissue homogenate, standards, and biotinylated monoclonal antibodyspecific and streptavidin-HRP were pipetted into these wells and then incubated at $37^{\circ} \mathrm{C}$ for 60 minutes. After washing, chromogen reagent $\mathrm{A}$ and chromogen reagent $B$ were added, and they were acted upon by the bound enzyme to produce a color. They were incubated at $37^{\circ} \mathrm{C}$ for 10 minutes, and then a stop solution was added. The intensity of this colored product was directly proportional to the concentration of rat TNF- $\alpha$ present in the original specimen. At the end of the course, the well plates were read at $450 \mathrm{~nm}$ using a microplate reader (Bio-Tek). The absorbance of the samples was estimated with formulas that used standard graphics.

\section{Histopathological examination}

The removed tissues were fixed in a 10\% formalin solution for 24 hours. Sections of $4 \mu \mathrm{m}$ thickness were taken from the paraffin blocks that were obtained following the routine tissue monitoring and stained with hematoxylin \& eosin. All sections were evaluated under light microscopy (Olympus BX 52, Olympus, Tokyo, Japan) by a pathologist who was not aware of the treatment protocols.

\section{Statistical analysis}

The results of the experiments were presented as the mean \pm standard deviation. The analysis of variance test was used to determine the significance of the difference between the groups, followed by the post hoc TukeyHSD test. The statistical analyses were performed using IBM SPSS Statistics version 20 (IBM Co., Armonk, NY, USA) at a significant level of $p<0.05$.

\section{RESULTS}

MDA, MPO, and tGSH analysis results

MDA $(5.7 \pm 0.12 \mu \mathrm{mol} / \mathrm{g}$ protein $)$ increased significantly 

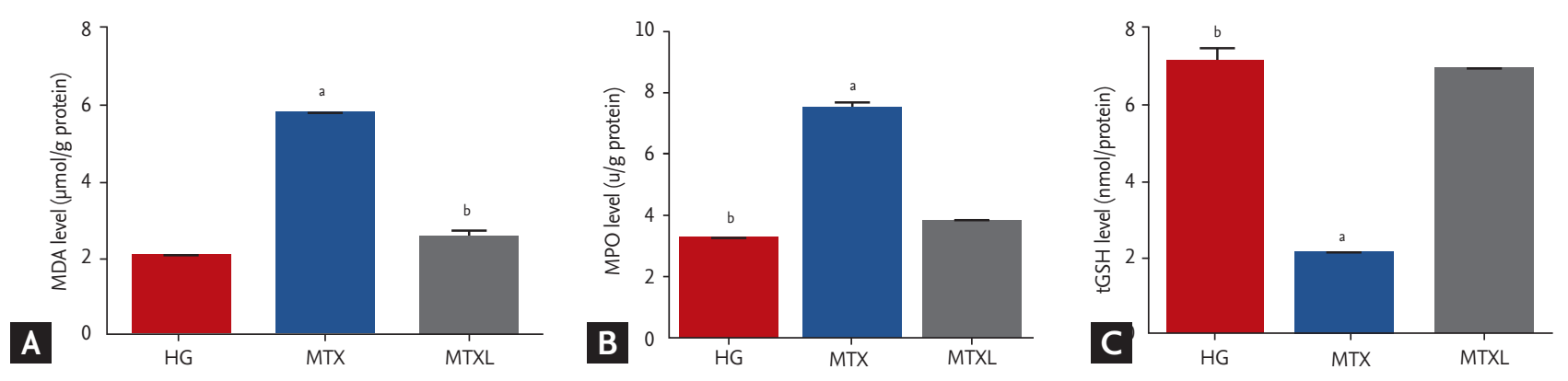

Figure 1. Effects of methotrexate (MTX) and lutein on the levels of (A) malondialdehyde (MDA), (B) myeloperoxidase (MPO), and $(\mathrm{C})$ total glutathione (tGSH) in the lung tissue of rat groups. MTXL, MTX + lutein. ${ }^{\mathrm{a}} \mathrm{p}<0.0001$ according to the healthy group (HG) group, ${ }^{\mathrm{b}} \mathrm{p}<0.0001$ according to the MTX group.
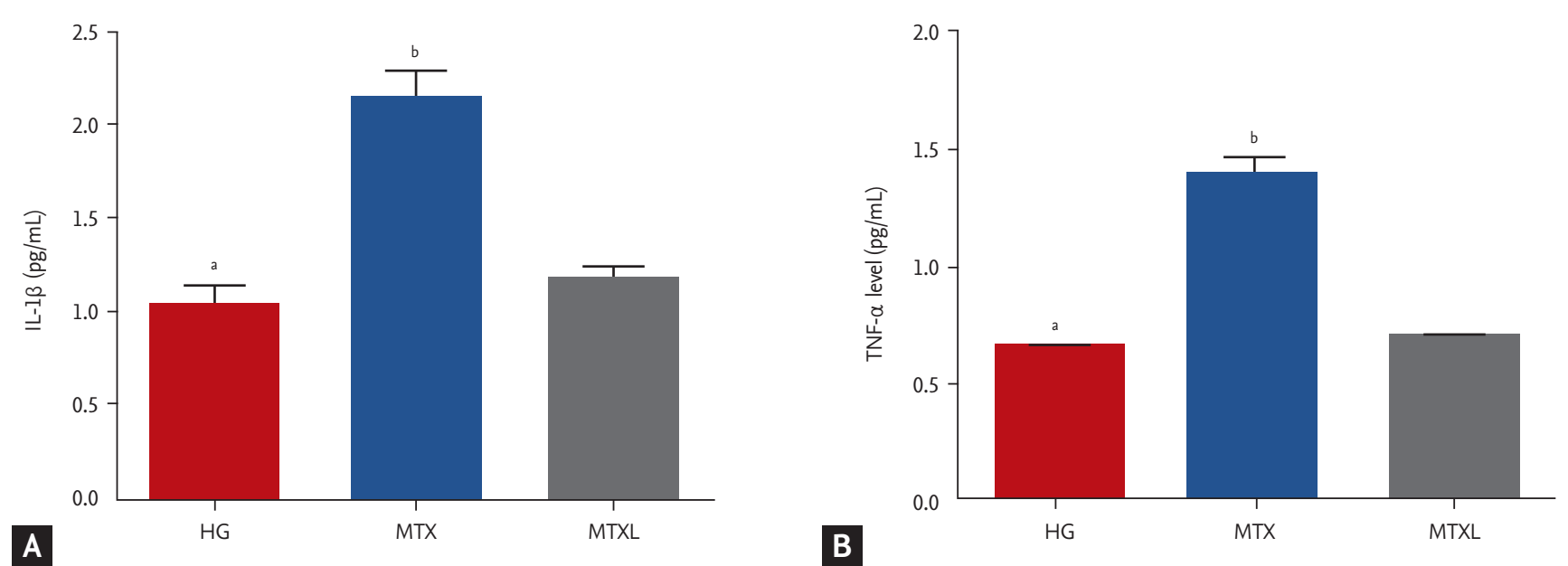

Figure 2. Effects of methotrexate (MTX) and lutein on the levels of (A) interleukin 1 beta (IL-1 $\beta$ ) and (B) tumor necrosis factor alpha (TNF- $\alpha$ ) in the lung tissue of rat groups. MTXL, MTX + lutein. ${ }^{\mathrm{a}} \mathrm{p}<0.0001$ according to the healthy group (HG) group, ${ }^{\mathrm{b}} \mathrm{p}$ $<0.0001$, according to the MTX group.

in the lung tissue of the MTX group in comparison with the MTXL $(2.5 \pm 0.17 \mu \mathrm{mol} / \mathrm{g}$ protein $)$ and HG $(2.0 \pm 0.09$ $\mu \mathrm{mol} / \mathrm{g}$ protein) groups $(p<0.0001)$ (Fig. 1A). MPO activity increased in the MTX group $(7.4 \pm 0.24 \mathrm{u} / \mathrm{g}$ protein $)$ in comparison with the MTXL $(3.8 \pm 0.10 \mathrm{u} / \mathrm{g}$ protein $)$ and HG (3.2 $\pm 0.86 \mathrm{u} / \mathrm{g}$ protein) groups $(p<0.0001)$ (Fig. $1 \mathrm{~B})$. tGSH in the MTX group $(2.0 \pm 0.08 \mathrm{nmol} / \mathrm{g}$ protein $)$ decreased significantly in comparison with the MTXL (6.9 $\pm 0.11 \mathrm{nmol} / \mathrm{g}$ protein $)$ and $\mathrm{HG}(7.1 \pm 0.31 \mathrm{nmol} / \mathrm{g}$ protein $)$ groups $(p<0.0001)$ (Fig. 1C).

\section{II-1 $\beta$ and TNF- $\alpha$ results}

MTX increased IL-1 $\beta$ significantly in the lung tissue (2.1 $\pm 0.14 \mathrm{pg} / \mathrm{mL})$ in comparison with the MTXL $(1.2 \pm 0.07$ $\mathrm{pg} / \mathrm{mL})$ and HG $(1.0 \pm 0.09 \mathrm{pg} / \mathrm{mL})$ groups $(p<0.0001)$ (Fig. 2A). TNF- $\alpha(1.4 \pm 0.07 \mathrm{pg} / \mathrm{mL})$ was higher in the
MTX group than in the MTXL $(0.71 \pm 0.02 \mathrm{pg} / \mathrm{mL})$ and HG $(0.66 \pm 0.03 \mathrm{pg} / \mathrm{mL})$ groups (Fig. $2 \mathrm{~B})$.

\section{Histopathological results}

Fig. 3 shows the normal visual epithelium, alveoli, pulmonary artery, and bronchial epithelium structure in the lung tissues of the HG group. The microscopic examination of the HG animal group yielded no pathological findings. Significant polymorphonuclear neutrophil (PNL) infiltration, severe hemorrhage, alveolar destruction, and edema were observed in the lung tissue of the MTX group (Fig. 3B). However, the lung tissues of the MTXL group that were given lutein showed a near-normal appearance except for slight thickening, dilatation, and congestion in the vessels and mild alveolar edema (Fig. 3C). 

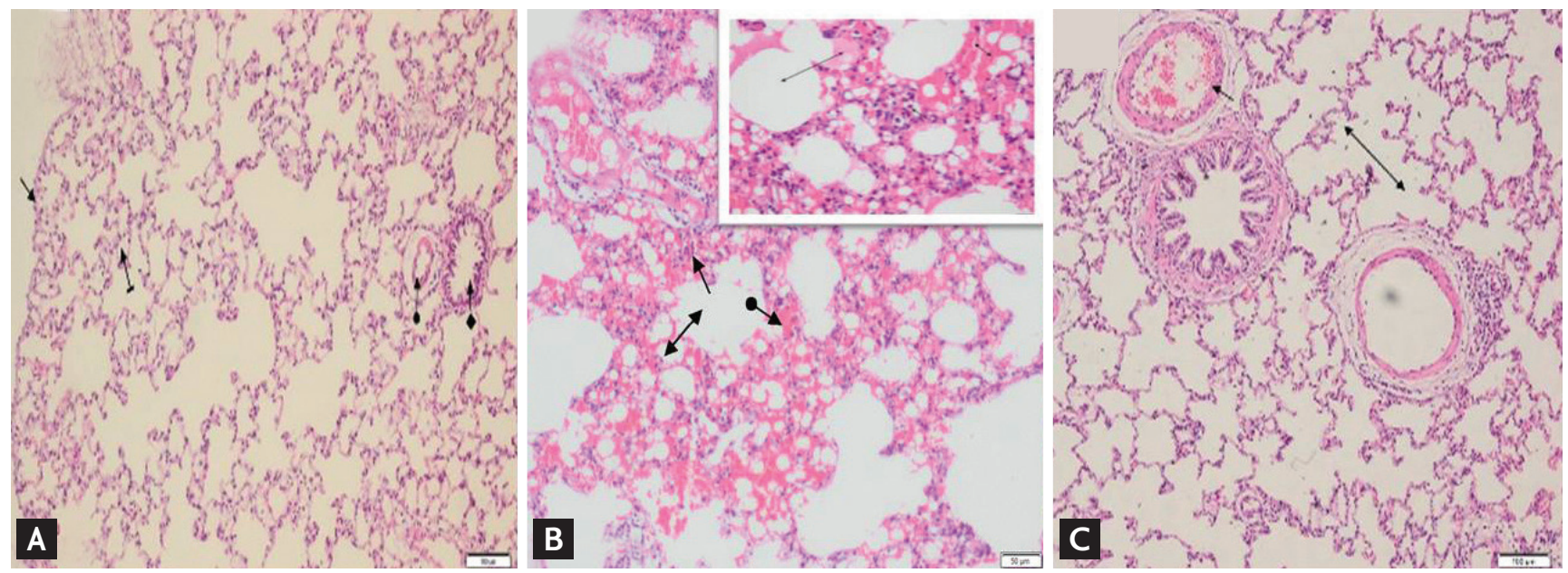

Figure 3. (A) The normal visceral epithelium (straight arrow), alveolar (striped arrow), pulmonary artery (round arrow), and bronchial epithelium (square arrow) structures are observed in the lung tissue of the healthy group animal group (H\&E, $\times 100)$. (B) The animal group treated with methotrexate shows significant polymorphonuclear neutrophil infiltration (straight arrow), severe hemorrhage (striated arrow), alveolar destruction (bilateral arrow), and edema in the lungs (H\&E, ×100). (C) The vascular wall of lutein-treated lung tissue is seen as normal, except for slight thickening, dilatation, congestion (flat arrow), and mild alveolar edema (double sided arrow) (H\&E, ×100).

\section{DISCUSSION}

In this study, the effect of lutein on MTX-induced oxidative pulmonary damage in rats was investigated biochemically and histopathologically. MTX administered at a single dose of $20 \mathrm{mg} / \mathrm{kg}$ significantly increased the amount of MDA in the lung tissues of the animals in comparison with the lutein and HGs. MDA is an indicator of oxidative stress and is produced during the lipid peroxidation of tissues [19]. MTX was recently reported to cause oxidative stress in lung tissue with a single dose of $20 \mathrm{mg} / \mathrm{kg}$ [20]. Kahraman et al. [21] reported a significant increase in MDA in the lung tissue of animals administered with $5 \mathrm{mg} / \mathrm{kg}$ MTX four times per day. Arpag et al. [20] demonstrated that oxidative stress was one of the main causes of MTX-induced lung damage. The findings from our experimental results and the literature show that MTX causes oxidative stress in lung tissue.

The MPO activity in the lung tissue of animals that were given MTX alone increased significantly in comparison with the lutein and HGs. MPO is an endogenous oxidizing lysosomal enzyme available in PNLs and monocytes that catalyzes the reaction between chloride ions and hydrogen peroxide to generate hypochlorous acid and other reactive oxygen species [22]. The progres- sion and control of inflammation are significantly affected by mediators produced by PNLs accumulating at the site of inflammation [23]. MPO is one of the important proinflammatory mediators secreted from PNLs, and it indicates inflammation [22]. High levels of MPO indicate PNL accumulation in lung tissues and the exacerbation of MTX-induced oxidative damage [20]. These findings are consistent with our experimental results.

Oxidative stress is evaluated through the oxidant-antioxidant balance [8]. In our study, the MDA and MPO levels were high in the lung tissues of animals that were given MTX, and the levels of tGSH, which is an endogenous antioxidant, were low. Our results suggest that the oxidant-antioxidant balance in the lung tissue of the MTX group deteriorated in favor of the oxidants. An increase in oxidant levels and a decrease in antioxidant levels were observed in various models of damage formed in living tissues [24]. This damage is known as oxidative stress [8].

Proinflammatory cytokine levels of IL-1 $\beta$ and TNF- $\alpha$, which were usually used to determine inflammation, were significantly increased in the lung tissues of MTX-treated animals. IL- $1 \beta$ and TNF- $\alpha$ are primary inflammatory cytokines produced by monocytes and macrophages in response to a range of stimuli, including various microbial products, activated $\mathrm{T}$ cells, immune 
complexes, and the combined action of other cytokines. They cause leucocytes to move out of capillaries and accumulate at sites of injury or infection [20]. In the tissues of the HG, the proinflammatory and anti-inflammatory cytokines were at equilibrium. This equilibrium changed in favor of the proinflammatory cytokines in MTX-induced lung toxicity [25]. These findings are consistent with our experimental results.

Our biochemical test results showed that lutein suppressed MTX-induced oxidative stress and inflammation in the lung tissue. In the literature, the protective effect of lutein on tissues was due to its antioxidant and anti-inflammatory properties $[26,27]$. Wang et al. [28] reported that lutein inhibited the production of MDA, which is the end product of lipid peroxidation and is an antioxidant. In addition to lipid peroxidation, lutein suppressed TNF- $\alpha$, IL-1 $\beta$, and NF- $\kappa \beta$ production and increased the amount of GSH [14]. The protective effect of lutein on oxidative stress, inflammation, and angiogenesis was reported to be due to the multiple active compounds resulting from oxidative metabolism [29,30]. Studies showed that the antioxidant and anti-inflammatory activity of lutein did not reduce its anticancer effects [31].

The results of our biochemical tests obtained from all groups are consistent with the histopathological findings. The MDA, MPO, IL-1 $\beta$, and TNF- $\alpha$ levels were high and tGSH was low in the MTX group. Furthermore, PNL infiltration, severe hemorrhage, alveolar destruction, and edema were observed. Lutein prevented the explicit MTX-induced PNL infiltration in lung tissue, severe hemorrhage, alveolar destruction, and alleviated edema. Arpag et al. [20] reported similar pathological findings in the lung tissues of the MTX group, in which oxidant and inflammatory markers were high and antioxidants were low. In another study, similar pathological findings were observed in MTX-induced lung oxidative damage [32]. Studies linking pathological changes, such as interstitial edema, alveolar damage, and PNL infiltration, to MTX-induced oxidative stress in the lung tissue of animals are also available [33].

As a result, MTX has been shown to be biochemically and histopathologically responsible for oxidative damage and inflammation in the lung tissue of animals. We found that lutein suppressed MTX-induced oxidative stress and inflammation in the lung tissue. Our results show that lutein protects the lung tissue from the toxic effect of MTX. This finding suggests that lutein may be useful in preventing MTX-induced lung toxicity.

Primary care is important because it is the first point of contact with patients in the health care system [34]. The effectiveness of the primary health care system provides significant gains in the follow-up and management of chronic diseases [35,36]. Given the characteristics of family medicine as defined by the World Organization of National Colleges, Academies, and Academic Associations of General Practitioners/Family Physicians Europe, family physicians have an important role in the management of chronic diseases [37]. If patients with chronic diseases using MTX present with fever, chills, unproductive cough, malaise, dyspnea, and chest pain that are progressive over several days, family physicians should consider MTX-induced pneumonitis and refer the patients for further diagnosis and treatment [38].

\section{KEY MESSAGE}

1. This study shows biochemically and histopathologically that lutein protects the lung tissue from the toxic effect of methotrexate (MTX).

2. We suggest that the pulmonary protective effects of lutein be tested clinically in combination with MTX in the treatment of rheumatologic diseases or cancers.

\section{Conflict of interest}

No potential conflict of interest relevant to this article was reported.

\section{REFERENCES}

1. Moisa A, Fritz P, Benz D, Wehner HD. Iatrogenically-related, fatal methotrexate intoxication: a series of four cases. Forensic Sci Int 2006;156:154-157.

2. Abolmaali SS, Tamaddon AM, Dinarvand R. A review of therapeutic challenges and achievements of methotrexate delivery systems for treatment of cancer and rheumatoid arthritis. Cancer Chemother Pharmacol 2013;71:1115-1130.

3. Ohosone Y, Okano Y, Kameda H, et al. Toxicity of low- 
dose methotrexate in rheumatoid arthritis: clinical characteristics in patients with MTX-induced pancytopenia and interstitial pneumonitis. Ryumachi 1997;37:16-23.

4. Altindag O, Kucukoglu B. Intoxication due to high dose methotrexate in a patient with rheumatoid arthritis: a case report. Arch Rheumatol 2011;26:58-60.

5. Brunton LL, Chabner BA, Knollmann B. Goodman \& Gilman's the Pharmacological Basis of Therapeutics. 12th ed. New York (NY): McGraw Hill Professional, 2011.

6. Yamauchi Y, Okazaki H, Desaki M, et al. Methotrexate induces interleukin-8 production by human bronchial and alveolar epithelial cells. Clin Sci (Lond) 2004;106:619-625.

7. Hsu DC, Katelaris CH. Long-term management of patients taking immunosuppressive drugs. Aust Prescr 2009;32:68-71.

8. Kisaoglu A, Borekci B, Yapca OE, Bilen H, Suleyman H. Tissue damage and oxidant/antioxidant balance. Eurasian J Med 2013;45:47-49.

9. Huang C, Hsu P, Hung Y, et al. Ornithine decarboxylase prevents methotrexate-induced apoptosis by reducing intracellular reactive oxygen species production. Apoptosis 2005;10:895-907.

10. Alamir I, Boukhettala N, Aziz M, Breuille D, Dechelotte P, Coeffier M. Beneficial effects of cathepsin inhibition to prevent chemotherapy-induced intestinal mucositis. Clin Exp Immunol 2010;162:298-305.

11. Sommerburg O, Keunen JE, Bird AC, van Kuijk FJ. Fruits and vegetables that are sources for lutein and zeaxanthin: the macular pigment in human eyes. $\mathrm{Br} \mathrm{J}$ Ophthalmol 1998;82:907-910.

12. Johnson EJ. The role of carotenoids in human health. Nutr Clin Care 2002;5:56-65.

13. Vijayapadma V, Ramyaa P, Pavithra D, Krishnasamy R. Protective effect of lutein against benzo(a)pyrene-induced oxidative stress in human erythrocytes. Toxicol Ind Health 2014;30:284-293.

14. Du SY, Zhang YL, Bai RX, Ai ZL, Xie BS, Yang HY. Lutein prevents alcohol-induced liver disease in rats by modulating oxidative stress and inflammation. Int J Clin Exp Med 2015;8:8785-8793.

15. Katyal T, Singh G, Budhiraja RD, Sachdeva M. Effect of lutein in development of experimental diabetic nephropathy in rats. Afr J Pharm Pharmacol 2013;7:2953-2959.

16. Ohkawa H, Ohishi N, Yagi K. Assay for lipid peroxides in animal tissues by thiobarbituric acid reaction. Anal Biochem 1979;95:351-358.
17. Bradley PP, Priebat DA, Christensen RD, Rothstein G. Measurement of cutaneous inflammation: estimation of neutrophil content with an enzyme marker. J Invest Dermatol 1982;78:206-209.

18. Sedlak J, Lindsay RH. Estimation of total, protein-bound, and nonprotein sulfhydryl groups in tissue with Ellman's reagent. Anal Biochem 1968;25:192-205.

19. Arikan DC, Bakan V, Kurutas EB, Sayar H, Coskun A. Protective effect of tadalafil on ischemia/reperfusion injury of rat ovary. J Pediatr Surg 2010;45:2203-2209.

20. Arpag H, Gul M, Aydemir Y, et al. Protective effects of alpha-lipoic acid on methotrexate-induced oxidative lung injury in rats. J Invest Surg 2018;31:107-113.

21. Kahraman H, Kurutas E, Tokur M, et al. Protective effects of erythropoietin and N-acetylcysteine on methotrexate-induced lung injury in rats. Balkan Med J 2013;30:99104.

22. Klebanoff SJ. Myeloperoxidase. Proc Assoc Am Physicians 1999;111:383-389.

23. Levy BD, Serhan CN. Resolution of acute inflammation in the lung. Annu Rev Physiol 2014;76:467-492.

24. Iraz M, Ozerol E, Gulec M, et al. Protective effect of caffeic acid phenethyl ester (CAPE) administration on cisplatin-induced oxidative damage to liver in rat. Cell Biochem Funct 2006;24:357-361.

25. Kim YJ, Song M, Ryu JC. Inflammation in methotrexate-induced pulmonary toxicity occurs via the p38 MAPK pathway. Toxicology 2009;256:183-190.

26. Kim JE, Leite JO, DeOgburn R, Smyth JA, Clark RM, Fernandez ML. A lutein-enriched diet prevents cholesterol accumulation and decreases oxidized LDL and inflammatory cytokines in the aorta of guinea pigs. J Nutr 2011;141:1458-1463.

27. Kim JH, Na HJ, Kim CK, et al. The non-provitamin A carotenoid, lutein, inhibits NF-kappaB-dependent gene expression through redox-based regulation of the phosphatidylinositol 3-kinase/PTEN/Akt and NF-kappaB-inducing kinase pathways: role of $\mathrm{H}(2) \mathrm{O}(2)$ in NF-kappaB activation. Free Radic Biol Med 2008;45:885-896.

28. Wang S, Wang M, Zhang S, Zhao L. Oxidative stress in rats with hyperhomo-cysteinemia and intervention effect of lutein. Eur Rev Med Pharmacol Sci 2014;18:359-364.

29. Sharavana G, Joseph GS, Baskaran V. Lutein attenuates oxidative stress markers and ameliorates glucose homeostasis through polyol pathway in heart and kidney of STZ-induced hyperglycemic rat model. Eur J Nutr 
2017;56:2475-2485.

30. Nidhi B, Sharavana G, Ramaprasad TR, Vallikannan B. Lutein derived fragments exhibit higher antioxidant and anti-inflammatory properties than lutein in lipopolysaccharide induced inflammation in rats. Food Funct 2015;6:450-460.

31. Chang J, Zhang Y, Li Y, et al. NrF2/ARE and NF- $\mathrm{B}$ pathway regulation may be the mechanism for lutein inhibition of human breast cancer cell. Future Oncol 2018;14:719-726.

32. Kurt A, Tumkaya L, Turut H, et al. Protective effects of infliximab on lung injury induced by methotrexate. Arch Bronconeumol 2015;51:551-557.

33. Selimoglu Sen H, Sen V, Bozkurt M, et al. Carvacrol and pomegranate extract in treating methotrexate-induced lung oxidative injury in rats. Med Sci Monit 2014;20:19831990.
34. Bodenheimer T, Wagner EH, Grumbach K. Improving primary care for patients with chronic illness. JAMA 2002;288:1775-1779.

35. Starfield B. Primary Care: Balancing Health Needs, Services, and Technology. New York (NY): Oxford University Press, 1998.

36. Akman M, Cifcili S. Family practice and chronic care model. Turk J Fam Pract 2010;14:32-37

37. WONCA European. The European Definition of General Practice/Family Medicine. Barcelona (ES): WONCA Europe, 2002.

38. Imokawa S, Colby TV, Leslie KO, Helmers RA. Methotrexate pneumonitis: review of the literature and histopathological findings in nine patients. Eur Respir J 2000;15:373381. 